\title{
COMPARING SEDIMENT TRAP DATA WITH EROSION MODELS FOR EVALUATION OF FOREST HAUL ROAD STREAM CROSSING APPROACHES
}

\author{
A. J. Lang, W. M. Aust, M. C. Bolding, K. J. McGuire, E. B. Schilling
}

\begin{abstract}
Soil erosion and sediment delivery models have been developed to estimate the inherent complexities of soil erosion, but most models are not specifically modified for forest operation applications. Three erosion models, the Universal Soil Loss Equation for forestry (USLE-Forest), Revised Universal Soil Loss Equation Version 2 (RUSLE2), and Water Erosion Prediction Project (WEPP), were compared to one year of trapped sediment data for 37 forest haul road stream crossings. We assessed model performance from five variations of the three erosion models: USLE-Roadway, USLE-Soil Survey, RUSLE2, WEPP-Default, and WEPP-Modified. Each road approach was categorized into one of four levels of erosion (very low, low, moderate, and high) based on trapped erosion rate data and erosion rates reported in recent peerreviewed literature. Model performance metrics included: (1) summary statistics and nonparametric analysis, (2) linear relationships, (3) percent agreement within erosion categories and tolerable error ranges, and (4) contingency table metrics. Sediment trap data varied from negligible $(<0.1)$ to hundreds of $\mathrm{Mg} \mathrm{ha}^{-1}$ year ${ }^{-1}$. The soil erosion models evaluated could estimate erosion within $5 \mathrm{Mg} \mathrm{ha}^{-1}$ year-1 for most approaches having erosion rates less than $11.2 \mathrm{Mg} \mathrm{ha}^{-1}$ year $^{-1}$, while models estimates varied widely for approaches that eroded at rates above $11.2 \mathrm{Mg} \mathrm{ha}^{-1}$ year-1. Kruskal-Wallis nonparametric analyses revealed that only WEPP-Modified estimates were not significantly different from trapped sediment data $(p \geq$ 0.107). While WEPP-Modified ranked best for most model performance metrics, the time, effort, modeling expertise, and uncertainty associated with model results may discourage the use of WEPP as a forest management tool. WEPP is better suited for researchers and government agencies that have the capability to measure extensive parameter data. Additional sensitivity analysis is needed to expand default parameters for forest roads within the WEPP and USLE models.
\end{abstract}

Keywords. Best management practices, Erosion, Haul roads, Soil erosion models, Stream crossing approaches.

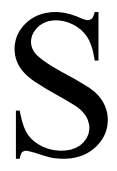
ediment is often the most significant nonpointsource (NPS) water pollutant associated with forest operations in the U.S. (SAF, 1995; EPA, 2005; Stuart and Edwards, 2006; Anderson and Lockaby, 2011). Sedimentation can adversely affect aquatic ecosystems, stream geomorphology, and water chemistry (Jackson et al., 2005; Jones et al., 2012; Pechenick et al., 2014). Erosion and subsequent sediment delivery to streams associated with silvicultural operations generally stem from the access system (i.e., haul roads, skid trails, stream crossings, and decks) (Elliot, 2000; Gucinski et al., 2001). The access system can generate surface runoff quickly because native soils are disturbed and compacted during construction. Reduced

Submitted for review in April 2016 as manuscript number NRES 11859; approved for publication by the Natural Resources \& Environmental Systems Community of ASABE in December 2016.

The authors are Albert J. Lang, Watershed and Conservation Staff Forester, Water Resources Branch, North Carolina Forest Service, Raleigh, North Carolina; W. Michael Aust, Professor, and M. Chad Bolding, Associate Professor, Department of Forest Resources and Environmental Conservation (FREC), Virginia Tech, Blacksburg, Virginia; Kevin J. McGuire, Associate Professor, FREC and Virginia Water Resource Research Center, Virginia Tech, Blacksburg, Virginia; Erik B. Schilling, Senior Research Scientist, National Council for Air and Stream Improvement, Inc., Aubrey, Texas. Corresponding author: Albert J. Lang, 512 N. Salisbury Street, 1616 Mail Service Center, Raleigh, NC 27699; phone: 919-857-4857; e-mail: aj.lang@ncagr.gov. infiltration rates and altered hillslope hydrology increase erosion rates, especially when heavily trafficked, and increase connectivity between terrestrial and aquatic ecosystems (Sheridan and Noske, 2007; NRC, 2008). Surface runoff is managed by road and trail designs and implementation of forestry best management practices (BMPs) (Walbridge, 1997). Forestry BMPs minimize erosion by increasing cover over disturbed soils and controlling runoff volume and velocity (Shepard, 2006; Edwards et al., 2015). Forest road BMPs include proper planning (e.g., road location, road design, timing of operations, and scheduled road maintenance) (Walbridge, 1997; Swift and Burns, 1999), increasing surfacing (e.g., adding gravel or vegetative cover) (Brown et al., 2013), and closing roads and trails following operations (Madej, 2001; Sawyers et al., 2012; Wade et al., 2012). Since the amendment of the Federal Water Pollution Control Act, commonly known as the Clean Water Act (CWA), in 1972, state NPS control programs have relied on BMPs to reduce erosion and sediment delivery from roads (Ice, 2004).

The U.S. Environmental Protection Agency (EPA) enforces the CWA statutes and determines appropriate policy for permitting exemptions. The EPA exempts many normal, ongoing silvicultural activities from the point-source permitting process for discharges of dredge or fill material in wetlands and streams of the U.S. (CWA, section 404). However, direct connection of roads to waterways at stream crossings has sparked legal debate over the EPA's silviculture exemp- 
tion. Specifically, legal cases (e.g., EPA, 2003) have focused on the EPA's decision to not regulate stormwater discharges from forest roads under the Phase II stormwater regulations. The U.S. Supreme Court considered whether stormwater discharge permits should be required for logging roads under the CWA (Boston, 2012; MacCurdy and Timmons, 2013) and ultimately ruled in favor of the EPA's authority to determine appropriate permitting exemptions. The EPA maintained that under section 402(p)(6) of the CWA, flexible approaches are well suited to address the complexity of forest road ownership, management, and use (EPA, 2012). However, legal cases regarding this matter continue (EPA, 2015).

Researchers have also reported high sediment delivery rates at road stream crossings with inadequate BMPs (Taylor et al., 1999; Lane and Sheridan, 2002; Croke et al., 2005; Aust et al., 2015). BMPs for stream crossings include stabilizing bare soil near the stream, maintaining adequate streamside management zones (SMZs), and choosing a proper structure, design, and location for the crossing (Aust et al., 2011). When appropriate stream crossing BMPs are correctly implemented, sediment delivery rates decrease (Aust et al., 2011; Brown et al., 2013; Nolan et al., 2015). The magnitude of sediment delivery from stream crossings is a complex issue governed by factors including road attributes, soil composition, and infiltration characteristics (Luce and Black, 1999; Lane and Sheridan, 2002; Brown et al., 2013). Soil erosion and sediment delivery models have been developed to estimate values for environmental parameters, but most models were not specifically designed for forest road applications. Researchers have modified agriculture models for forestry applications, e.g., the forest version of the Universal Soil Loss Equation (USLE-Forest) (Dissmeyer and Foster, 1984) and the Water Erosion Prediction Project (WEPP) (Elliot and Hall, 1997), but further model improvements are necessary for forest roads (Fu et al., 2010). In light of erosion model deficiencies, forest managers are drawn to use models because results can be easily generated. Additionally, model results may further justify the costs associated with BMP implementation.

Traditionally, two categories of soil erosion models have been applied in forest operation research: empirical and physical (Fu et al., 2010). Empirical models are derived from experiments or observations and have simpler model structure compared to physically based erosion models. Empirical models typically have fewer input parameters and are simpler to compute than physical models (Merritt et al., 2003). Because the data requirements and site characterizations are often less, empirical models are easier to implement in forest management decisions (Christopher and Visser, 2007). Some popular examples of empirical erosion models include the USLE and the revised USLE (RUSLE). The USLE method of estimating soil loss is a widely used erosion model because of its ease and ability to generate estimations in the field (Christopher and Visser, 2007). The USLE was originally designed to predict long-term annual soil loss from agricultural fields but was adapted for forest lands to predict sheet and rill erosion to the bottom of a hillslope (USLE-Forest; Dissmeyer and Foster, 1984). RUSLE version 2 (RUSLE2) is an enhanced version of the USLE and RUSLE models (Renard et al., 1997). RUSLE2 was devel- oped by the USDA Agriculture Research Service (USDAARS), the USDA Natural Resource Conservation Service (NRCS), and the Department of Biosystems Engineering and Environmental Science at the University of Tennessee. RUSLE2 uses the same process for estimating erosion as USLE-Forest but allows additional detail in input parameters, such as average temperature, monthly precipitation, slope profile breaks, permanent barriers, and specific management and support operations and their timing (Renard et al., 1991). Unlike the USLE, RUSLE2 is theoretically applicable to all land uses where raindrop impact and overland flow causes soil erosion (USDA-ARS, 2008). Researchers have also tested physically based erosion models for use in soil and water conservation, planning, and assessment (Flanagan et al., 2007).

Physically based models are driven by the understanding of mass, energy, and momentum conservation. The detailed model parameters allow further exploration of individual model components and their influence on erosional processes and sediment yields for the site at which they are applied. However, the number of inputs and differences among input measures make the application of physical models more cumbersome for forest management. WEPP was developed by the USDA-ARS and Purdue University for federal agencies that manage sites for soil and water conservation (Flanagan et al., 2007). WEPP is a physically based model that incorporates field observations and site-level information for predicting erosion and sediment yield. WEPP can be run for either a hillslope profile or a watershed structure (Flanagan et al., 2012). Researchers have improved and estimated the uncertainty of WEPP model runs to estimate sediment delivery from forest roads (Elliot et al., 1995; Laflen et al., 1997; Foltz et al., 2009), but management decisions should not be based solely on model predictions of sediment yield (Brown et al., 2016).

Comparisons of model predictions to observations are rare due to the associated costs of direct sediment measurements (Robichaud and Brown, 2002). Soil loss models and equations provide a time-efficient and cost-effective approach to evaluate BMPs and road designs (Fu et al., 2010). However, erosion estimates from models must be interpreted with caution, as issues with uncertainty are prevalent (Brazier et al., 2000). Few studies have compared model predictions to observed erosion using readily measureable field characteristics. Comparisons of erosion models with direct measures are necessary to assess and challenge existing model structures and input parameter data for the situations in which forest managers may use them (e.g., stream crossings, haul and skid roads). Revisions to the structure and parameter modifications within a model may improve agreement between observations and predictions but cannot be verified, validated, or fully confirmed in the natural world (Oreskes et al., 1994). Several researchers have designed experiments to compare erosion models with direct sediment measures in order to evaluate specific BMPs (Sawyers et al., 2012; Wade et al., 2012; Wear et al. 2013; Brown et al., 2016). However, few studies have evaluated erosion models using simple field measures on operational stream crossing approaches that do not have specific BMP treatments.

Overall, researchers indicate that both empirical and 
physical models are useful tools in predicting erosion, identifying erosion-prone areas, and ranking forestry BMP performances (Tiwari et al., 2000; Amore et al., 2004; Laflen et al., 2004; Croke and Nethery, 2006; Wade et al., 2012). Although the USLE, RUSLE2, and WEPP erosion models were not specifically developed for forest road applications, numerous researchers have used them to estimate erosion and sediment yields (Megahan et al., 2001; Aust et al., 2015; Nolan et al., 2015). Each model has limitations and a scope of usefulness that must be considered for sediment yield estimations (Brazier et al., 2000; Fu et al., 2010). Empirical models, such as USLE and RUSLE, may be better suited for managers with limited site information. Physical model, such as WEPP, require more input parameters but offer opportunities to modify the input parameters, which may allow closer estimates to observed values than empirical models on a wider range of sites.

\section{Study ObJectives}

Previous research clearly indicates that forest stream crossings have above-average potential for delivery of sediment to streams, and erosion models may prove useful for identifying erosion-prone areas. Ranking erosion-prone areas with erosion models could support management decisions to apply additional or more appropriate BMPs. The objectives of this study were to: (1) evaluate model performance of three erosion models using field-informed measures by comparing model simulations to trapped sediment measurements, and (2) assess model utility for identifying stream crossing approaches that may require additional BMPs. The models evaluated were versions of USLE-Forest (Dissmeyer and Foster, 1984), RUSLE2 (Toy et al., 1999), and WEPP (Elliot, 2004).

\section{MeTHODS}

\section{STUDY AREAS}

We selected and instrumented all 37 permanent forest haul road stream crossing approaches made available to us by MeadWestvaco Corporation (now WestRock), Virginia Tech, and the U.S. Forest Service. All stream crossing approaches were located in the Virginia Piedmont and Ridge and Valley physiographic regions (fig. 1). These regions are generally representative of topography in the Mountainous, Piedmont, and upper Coastal Plain regions of the southeastern U.S. and are the primary areas of concern for forest road erosion (Aust et al., 1996). All stream crossings were originally constructed across intermittent or perennial streams with road standards that would permit the weight of large operational equipment, transport trucks, and log truck traffic. SMZs were used adjacent to harvests, following Virginia Department of Forestry (VDOF) BMP guidelines (VDOF, 2011).

Twenty-one Piedmont approaches were instrumented in Appomattox and Buckingham counties of Virginia in June 2012. The topography of the Piedmont region is characterized by rolling hills with moderate slopes (USDA-NRCS, 2012). Typical January temperatures near these study areas range from $-4^{\circ} \mathrm{C}$ to $8^{\circ} \mathrm{C}$, and July temperatures range from $21^{\circ} \mathrm{C}$ to $30^{\circ} \mathrm{C}$. Average annual precipitation from historic weather data (1981 to 2010) is $120 \mathrm{~cm}$ occurring over 120 days (NOAA, 2015). Total rainfall data were collected daily from two personal weather stations affiliated with the Weather Underground service (WU, 2013) for Buckingham and Appomattox counties. Soil series identified along road approaches were Appomattox-Cullen complex, Chewacla, Codorus-Hatboro complex, Mecklenburg-Poindexter complex, Grassland-Delanco complex, Tatum-Manteo complex, Spears Mountain, and Spears Mountain-Bugley complex (USDA-NRCS, 2012). Piedmont sites were selected from seven intensively managed loblolly pine (Pinus taeda L.) plantations made available by MeadWestvaco Corporation (now owned by WestRock). Although these roads were primarily constructed for timber management activities, low volumes of traffic from hunt clubs were the primary uses of most Piedmont approaches during this study.

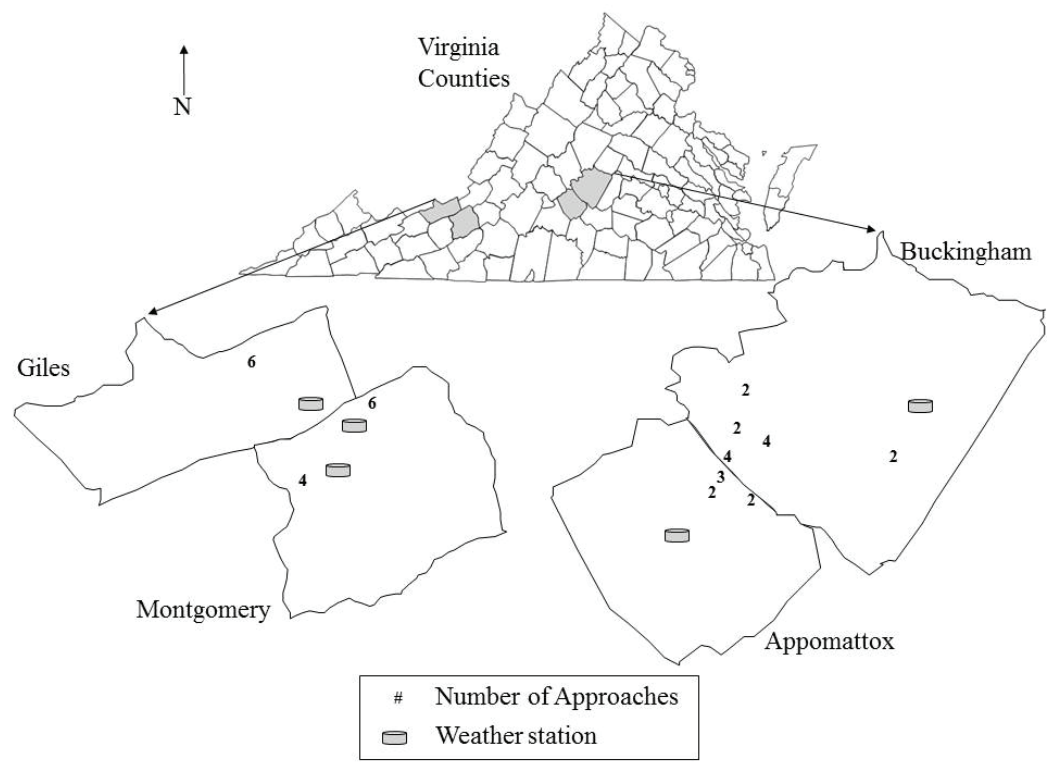

Figure 1. General vicinity map of the 37 stream crossing approaches and five weather stations in Appomattox, Buckingham, Giles, and Montgomery counties, Virginia (not to scale). Numbers represent the number of stream crossing approaches. 
Sixteen Ridge and Valley stream crossing approaches were instrumented in Montgomery and Giles counties of Virginia between July and November of 2012. The Ridge and Valley region is characterized by broad valleys separated by long linear ridges with low to moderate slopes (USDA-NRCS, 2012). Typical January temperatures near these study areas range from $-6^{\circ} \mathrm{C}$ to $5^{\circ} \mathrm{C}$, and July temperatures range from $16^{\circ} \mathrm{C}$ to $28^{\circ} \mathrm{C}$. Average annual precipitation from historic weather data (1981 to 2010) is $104 \mathrm{~cm}$ occurring over 130 days (NOAA, 2015). Total rainfall data were collected daily from three personal weather stations affiliated with the Weather Underground service (WU, 2013) within Giles and Montgomery counties. The following soil series were identified along road approaches in this region: Jefferson, Berks and Weikert, Oriskany, Laidig, and Craigsville (USDA-NRCS, 2012). Sites were selected from 12 stream crossings on two haul roads (Turkey Nest Road and White Rocks Road) in the George Washington and Jefferson National Forest and four stream crossings in the Virginia Tech Fishburn Forest. The current purpose of the Forest Service roads is recreation (restricted public vehicle access), crop tree release activities, and small firewood cutting, although the roads were originally constructed for timber harvests. The Virginia Tech school forest road serves as access for periodic teaching exercises and maintenance of the municipal water system and private cellphone towers, but the road has served for three separate timber harvests. The most recent maintenance to road surfaces on both the National Forest and Virginia Tech school forest roads was two to five years prior to project installation.

\section{TREATMENT INSTALLATION AND SEDIMENT MEASUREMENTS}

Stream crossing approaches were defined as the road areas sloping toward stream crossings. At the lowest elevation nearest the stream crossing, a narrow trench was hand-excavated at a $30^{\circ}$ to $45^{\circ}$ angle across the road, and a thick rubber conveyor belt was partially buried in the trench, leaving approximately $15 \mathrm{~cm}$ of belt exposed above the road surface (fig. 2). Water and sediment generated by overland flow were diverted from the road surface by the belt into a roadside silt catchment area. This design allowed vehicular traffic while approximating the sediment delivery to the stream. Prefabricated non-biodegradable silt fences with a permittivity rating of $0.05 \mathrm{~s}^{-1}$ (TerraTex, Hanes Geo Components, Winston-Salem, N.C.) were used for the silt catchment areas. Additional wooden grade stakes were used to support the fabric. We assumed that sediment caught within the silt fence traps would have otherwise been deposited into the stream due to the close proximity. The conveyor belts were installed over a six-month period (June to November 2012).

Within the silt catchment areas, ten rebar pins marked the locations for elevation measurements of trapped sediment (fig. 3). Additional pins were added as sediment accumulated in order to better estimate the deposited sediment. The pin placement was generally an $X$ by $Y$ grid with adjustments as necessary where prohibited by rock. We assumed that the silt fence efficiencies (i.e., the amount of sediment trapped compared to the amount that passed through the silt fence) were constant at each location. Elevations behind pins were measured using differential leveling with a total station (model SET-520, Sokkia, Tokyo, Japan). Sediment deposits were measured approximately every two months over a oneyear period, with all sites measured exactly one year after installation. Elevation change (sediment deposits in $\mathrm{m}$ ) and depositional area $\left(\mathrm{m}^{2}\right)$ were recorded during each site visit and multiplied to calculate the sediment volume $\left(\mathrm{m}^{3}\right)$. Three bulk density samples were collected after one year of sediment accumulation using the soil core method (Grossman and Reinsch, 2002) for each sediment catch area and analyzed. Sediment volume accumulation was multiplied by mean bulk density $\left(\mathrm{Mg} \mathrm{m}^{-3}\right)$ to calculate sediment mass $(\mathrm{Mg})$. Sediment mass corresponding to each repeated measure was expressed as mass per unit area $\left(\mathrm{Mg} \mathrm{ha}^{-1}\right)$ by divid-

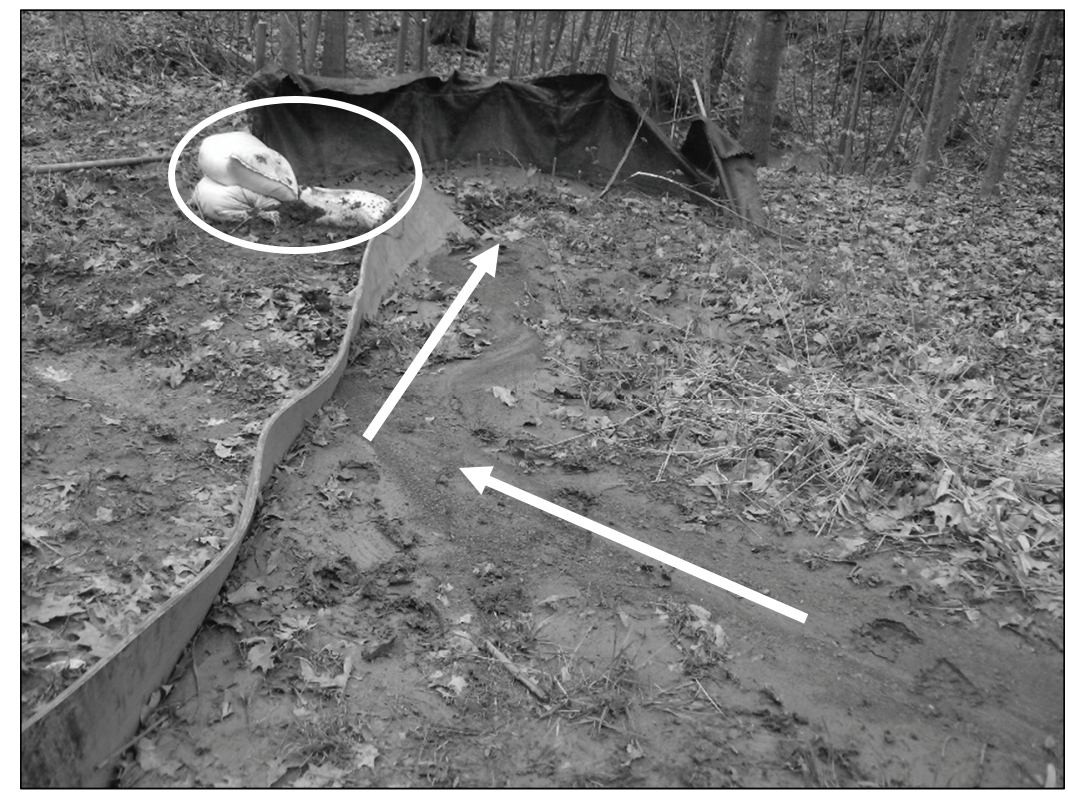

Figure 2. Rubber conveyor belt used to divert runoff into a silt fence catchment area. Arrows indicate the direction of surface runoff from the road surface to the silt fence catchment area. Sandbags (circled) were used to prevent flow from escaping around the edge of the silt fence. 


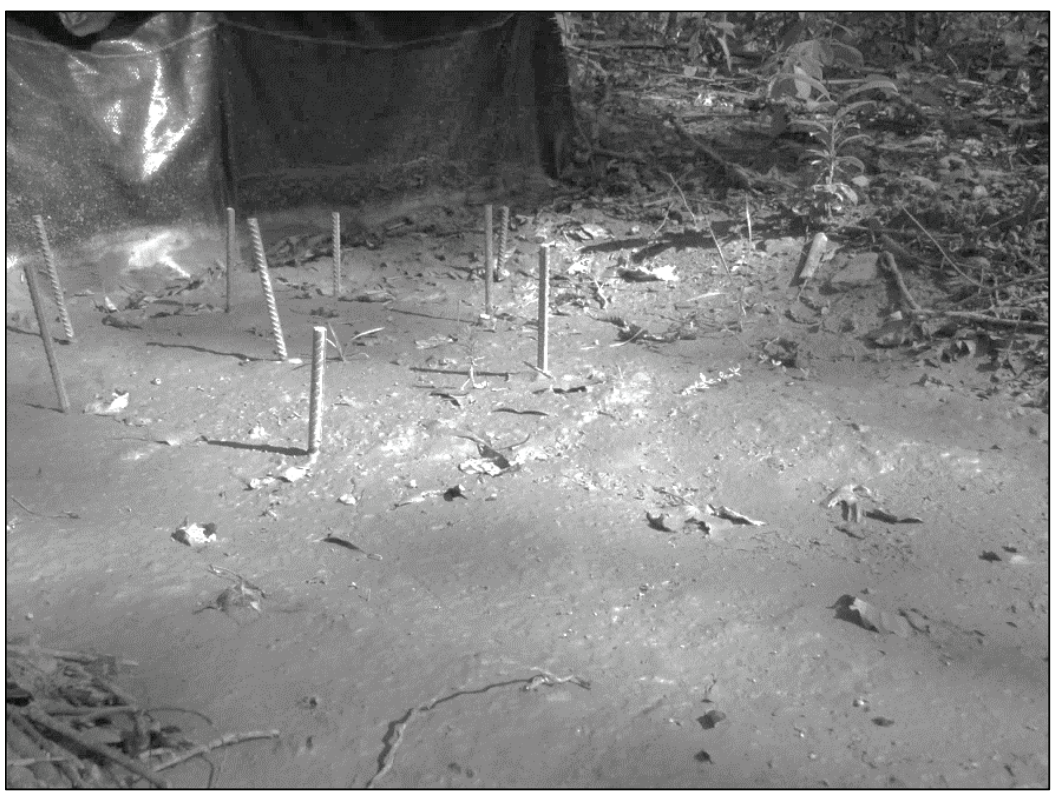

Figure 3. Silt fence catchment area with rebar pins marking the measurement locations.

ing the measured sediment deposit by the road surface area (area from the conveyor belt to the nearest water control structure) and later summed over one year to express potential sediment delivery on an annual basis $\left(\mathrm{Mg} \mathrm{ha}^{-1}\right.$ year $\left.^{-1}\right)$.

Following installation of the conveyor belt, approach characteristics and attributes hypothesized to influence erosion were recorded. Road prism dimensions (distance to water control structure, width, slope, and cutslope ratio) were surveyed using a total station. Width of SMZs and depth of gravel were measured with a tape. Bare soil percentages were collected seasonally and quantified by walking a zigzag pattern on the road running surface to the nearest water bar and counting the number of steps where the toe of the boot contacted bare soil (i.e., count of bare soil steps / total number of steps $\times 100=$ percent bare soil) (Brown et al., 2013). Percent cover on the road surface was determined during four seasonal measurements and then averaged to account for the effect of vegetative growth and tree litterfall. Gravel coverages were quantified in a similar manner. Canopy cover was measured seasonally using a spherical densitometer (Strickler, 1959). Surface soil composites were collected from running surfaces and anticipated sediment source areas (i.e., bare soil areas along the approach that were not on the running surface, such as cutslopes). Soil samples were analyzed for particle size classes using the hydrometer method (Gee and Or, 2002). Approach categorical variables were road template (insloped, outsloped, or crowned) and road shape (flat, concaved, convex, and S-shaped).

\section{USLE-FOREST}

The forestland version of the USLE is comprised of six factors that are multiplied together to estimate the amount of soil displacement to the bottom of a slope (Dissmeyer and Foster, 1984). The six components are rainfall and runoff factor $(R)$, soil erodibility factor $(K)$, slope length factor $(L)$, slope steepness factor $(S)$, cover and management factor $(C)$, and support practice factor $(P)$. The factors were computed in English units, and subsequent USLE equations presented are also in English units. Final soil loss results $(A)$ were converted from English to metric. The rainfall and runoff factor $(R)$ for the Piedmont and Ridge and Valley sites was 180 and 145 hundreds of $\mathrm{ft}$ tons acre $\mathrm{a}^{-1} \mathrm{year}^{-1}$, respectively. These values were derived from the isoerodent map provided in the USLE-Forest manual (Dissmeyer and Foster, 1984). A soil erodibility factor $(K)$ was calculated for each approach using two methods. USLE-Roadway used the percent sand, silt, and clay determined in the particle size analysis (Gee and Or, 2002). The following equation was used to calculate $K$ for this method:

$$
\begin{aligned}
K & =2.1 M^{1.14}\left(10^{-6}\right) \times(12-a) \\
& +0.0325(b-2)+0.025(c-3)
\end{aligned}
$$

where $M=$ (percent silt + very fine sand $) \times(100-$ percent clay), $a$ is the percent organic matter, $b$ is the structure code, and $c$ is the profile permeability class. The second method (USLE-Soil Survey) used the USDA-NRCS soil survey erodibility values given for the B horizon identified at each approach, as the road construction process removes the topsoil and exposes subsoils. A total station was used to measure slope length $(L)$ and steepness $(S)$. The values collected were used in the following equation to calculate the LS factor:

$$
L S=(\lambda / 72.6)^{m}\left(65.41 \sin ^{2} \theta+4.65 \sin \theta+0.065\right)
$$

where $\lambda$ is the slope length (feet), $\theta$ is the slope angle (degrees), and $m$ is 0.2 for $<1 \%$ slopes, 0.3 for $1 \%$ to $3 \%$ slopes, 0.4 for $3.5 \%$ to $4.5 \%$ slopes, and 0.5 for $\geq 5 \%$ slopes (Dissmeyer and Foster, 1984). The cover, management, and support practices (CP) values for a tilled soil were used to approximate topsoil disturbance and traffic effects of haul roads. CP subfactors include: (1) bare soil, residual binding, and soil reconsolidation, (2) canopy effect, (3) steps, (4) onsite storage, (5) invading vegetation, and (6) contour tillage. The bare soil, residual binding, and soil reconsolidation sub- 
factor was estimated using the bare soil estimates measured seasonally during site visits. The remaining CP subfactors were estimated according to each approach condition. Erosion rates were calculated seasonally for each approach. This provided four erosion rates per approach over one year. The four erosion rates of each approach were averaged to determine the mean annual erosion rate $\left(\mathrm{Mg} \mathrm{ha}^{-1}\right.$ year $\left.^{-1}\right)$.

\section{RUSLE2}

Erosion estimates were calculated using RUSLE2 (ver. 2.5.7.7). Unlike USLE, RUSLE2 allows additional parameter inputs that can be adjusted to more adequately mimic site conditions. First, climate data were accessed from the NRCS National RUSLE2 database (USDA-NRCS, 2015) for Appomattox, Buckingham, Giles, and Montgomery counties of Virginia. These datasets included average daily and monthly values from 1961 to 1990 for rainfall and temperature. We used these datasets because we did not measure rainfall intensity, which is needed to calculate erosivity density within RUSLE2 (USDA-ARS, 2008). Second, a soil file can be downloaded from the RUSLE2 database or created for sitespecific conditions. Within the soil files, there is information on soil texture, soil erodibility index, hydrologic class using curve number methodology, and acceptable soil loss rates. New soil files were created by modifying generic soil files with general soil textures (i.e., sand, silt, and clay combinations) and qualitative levels of soil organic matter (i.e., low, moderate, high) and permeability (slow, moderate, fast). For this study, soil files for each approach were generated according to soil particle size determined in laboratory analysis of soil texture. Due to the original construction template and traffic, we assumed low soil organic matter and slow permeability for all approaches. All other soil parameters remained at default settings. Third, slope topography can be created having no breaks or multiple breaks within the slope profile. Elevation data were collected at points along each approach where obvious changes in the slope shape or grade occurred, and these elevations were used to create detailed profiles within the model.

The fourth component was a management file that described surface conditions. Within the software, there are management files that describe highly disturbed land. The gravel surface file most closely approximated forest haul roads, but the operations within these files did not specifically reflect forest road activities (e.g., traffic level, surface condition, and road template). Management files were created for each road approach by modifying the "gravel surface, fresh" management file. Within this file, two default operations are implemented ("blade fill material" and "add mulch"). The blade fill material operation can be changed to several different options, but only "blade cut material" or "blade fill material" seemed suitable for characterizing forest haul roads. The "blade cut material" operation generates less erosion than "blade fill material". The second operation ("add mulch") allows users to choose from a variety of mulching agents. The type of mulch applied in this study was "mulch materials/rock". The rate of application was adjusted until the resulting "cover from addition" described the mean approach soil coverage. Application rates used within RUSLE2 varied from 11.4 to $700 \mathrm{Mg} \mathrm{ha}^{-1}$ to achieve meas- ured mean soil coverage. Sediment delivery estimates were made for a one-year model run.

\section{WEPP}

WEPP (ver. 2012.8) was used to estimate erosion at each road approach. Files related to slope, climate, soils, and vegetation management were modified or created to develop hillslope profiles for each of the 37 road approaches. Similar to RUSLE2, WEPP contains an extensive database for climate, soils, and vegetation management files. However, there are more adjustable parameters in WEPP than in RUSLE2. The user may implement or modify files to fit a specific hillslope or watershed. We compared the use of WEPP as generally available with little modification (WEPP-Default) and WEPP with extensive modifications (WEPP-Modified); thus, two methods of attaining sediment yield estimates with WEPP were assessed. For both methods, slope files were created in the WEPP model similarly to the slopes created in RUSLE2. In addition to the RUSLE2 slope profile, WEPP has parameters regarding road surface width, road vertical shape (concave, convex, linear, or S-shaped), and aspect. These parameters were collected during the initial road survey using a total station and were input into both WEPP methods.

For the WEPP-Default method, minimal adjustments were made to the soil and management files with the premise of using easily accessible field information. Default management files were chosen based on their description and were not modified. Soil files were chosen based on mapped soil survey information. Climate data were simulated for 100 years using the CLIGEN weather generator. This method produces daily time series estimates for climate parameters in a selected location based on the nearest weather station with historic mean monthly measurements. The resulting WEPP-Default files were used in the simulation.

For the second method (WEPP-Modified), parameter values for climate, soils, and vegetation management procedures were modified based on measurements of site characteristics and communication with William Elliot (USDA Forest Service, personal communication, September 2015). Daily rainfall, minimum air temperature, and maximum air temperature data were collected from five privately owned and operated weather stations affiliated with the Weather Underground service (WU, 2013) located nearest the five groups of approaches. Data were recorded for the period of 1 January 2012 to 31 December 2013. To simulate rainfall, WEPP requires additional climate parameters, including duration, time to peak intensity, peak intensity, daily solar radiation, wind velocity, and wind direction. These parameters were generated using the "add climate location" function in WEPP. We selected the nearest weather station with associated CLIGEN files for each group of approaches to create a parameter (PAR) file. This method matches the observed data (e.g., rainfall and temperature) and averages the nonrecorded data from the selected weather station climate records. The five resulting climate files were used in the analysis.

Within the WEPP soil database, 16 default files specify the term "road surface". These files are differentiated with soil texture, road template, and/or surfacing. Soil files to be 
modified were selected by the known road surface texture, surfacing (e.g., gravel, vegetated, bare), and road template for each approach. WEPP-Modified soil files were modified by adjusting percent sand, silt, and clay and keeping the default settings for interrill erodibility, rill erodibility, critical shear, and effective hydraulic conductivity. Within the WEPP vegetation management database, eight road management files could potentially be appropriate for haul roads. Management files require input for initial conditions that start on January 1. Nine initial condition files could be suited for haul roads. Within the initial condition files, 21 parameters may be adjusted. One of the 21 parameters is the initial plant condition, which has another subset of 33 parameters grouped into plant growth and harvest, temperature and radiation, canopy, leaf area index, root, senescence, and residue parameters. The combined effects of gravel and litterfall on the road surface cover were modeled by modifying parameters within one of the eight default files. The parameters values that were adjusted for initial conditions were canopy cover, interrill and rill covers, and initial plant. Canopy cover (\%) was set to the recorded value during winter site visits. Interrill and rill covers were assigned the inverse values of percent bare soil recorded for winter site visits. Within the subset of initial plant parameters, canopy cover coefficient, decomposition rate, and biomass energy ratio were adjusted by trial and error to mimic canopy and road cover over the one-year study period. The resulting management files were used in the simulation.

\section{Data Analysis}

Our goal was to compare model estimates to trapped sediment erosion rates. A variety of methods were used to compare trapped sediment and modeled sediment erosion estimates, including: (1) summary statistics and a nonparametric analysis, (2) linear relationships, (3) percent agreement within erosion categories and tolerable error ranges, and (4) a contingency table.

We tested for statistically significant differences between the trapped sediment data and each modeling method. Trapped sediment erosion rates were not normally distributed nor varied equally. Data transformations of the sediment trap measures did not result in equal variance (Levene's test). Therefore, nonparametric Kruskal-Wallis methods were used to compare erosion rates between trapped sediment data and modeled estimates (Zar, 2010). Separations of significantly different medians were based on Wilcoxon each pair tests (Zar, 2010). All statistical analyses were completed in JMP (ver. 11, SAS Institute, Inc., Cary, $\mathrm{NC})$.

We categorized the trapped sediment data into four erosion rate categories (very low, low, moderate, and high): very low erosion rates were $<10 \mathrm{Mg} \mathrm{ha}^{-1}$ year $^{-1}$; low erosion rates were 10.1 to $25 \mathrm{Mg} \mathrm{ha}^{-1}$ year ${ }^{-1}$; moderate erosion rates were 25.1 to $50 \mathrm{Mg} \mathrm{ha}^{-1}$ year $^{-1}$; and high erosion rates were $>50 \mathrm{Mg} \mathrm{ha}^{-1}$ year $^{-1}$. Similar categories of erosion rate were reported by Morris et al. (2014) and Nolan et al. (2015) for forest haul road stream crossings with various levels of BMPs. Next, we assigned tolerance ranges within which the model estimates could deviate from the trapped sediment data. For the tolerance ranges, we assigned erosion rates of $\pm 20, \pm 10, \pm 5, \pm 3$, and $\pm 1 \mathrm{Mg} \mathrm{ha}^{-1}$ year $^{-1}$ for trapped sediment erosion rates of $>100,99.9$ to $50,49.9$ to $10,9.9$ to 1 , and $<1 \mathrm{Mg} \mathrm{ha}^{-1}$ year $^{-1}$, respectively. These values were chosen based on the professional experiences of the authors. For example, a measured erosion rate of $75 \mathrm{Mg} \mathrm{ha}^{-1}$ year-1 that was $^{-1}$ modeled between 85 and $65 \mathrm{Mg} \mathrm{ha}^{-1}$ year $^{-1}$ would be within our tolerance range. An erosion rate modeled above $85 \mathrm{Mg}$ $\mathrm{ha}^{-1}$ year $^{-1}$ or below $65 \mathrm{Mg} \mathrm{ha}^{-1}$ year $^{-1}$ would be above or below the tolerance range, respectively.

Contingency tables are another method for assessing model performance. Contingency tables can be used to report the behavior of environmental models at a specific level, known as the "trigger" or "alarm" (Bennett et al., 2013). For this study, we chose $11.2 \mathrm{Mg} \mathrm{ha}^{-1}$ year $^{-1}$ as the trigger. We chose the trigger based on the NRCS allowable erosion rates (T-factor) for the soil series involved in the study, which range from 2.2 to $11.2 \mathrm{Mg} \mathrm{ha}^{-1}$ year $^{-1}$. The $\mathrm{T}$-factor is the tolerable rate of soil loss at which the quality of a soil as a medium for plant growth can be maintained (USDA-NRCS, 2011). Additionally, we examined the literature for high versus low erosion rates on roads and determined that $11.2 \mathrm{Mg}$ $\mathrm{ha}^{-1}$ year $^{-1}$ generally captured the concept of high versus low erosion rates for forest roads. Brown et al. (2013) and Kochenderfer and Helvey (1987) found that forest roads with adequate BMPs typically produce erosion rates below our trigger. We calculated the number of occurrences in which the trapped sediment data and model estimates were both above the trigger (hits), both below the trigger (correct negatives), trapped sediment above and modeled estimate below the trigger (miss), and trapped sediment below and modeled estimate above the trigger (false alarm). From these results, it is possible to derive a number of measures of model performance (Bennett et al., 2013). We reported model accuracy, bias score, probability of detection, false alarm ratio, and success index metrics from the contingency table results for each model. From a management perspective, erosion models that can correctly identify approaches above a threshold would be beneficial for determining which approaches would benefit from additional BMPs.

\section{RESULTS \\ SUMMARY STATISTICS AND NONPARAMETRIC Analysis of Model Performance}

Summary statistics of approach characteristics by region are provided in table 1. Additional site descriptions and BMP levels for the roads in this study were previously reported by Lang (2016). In general, approaches in the Piedmont region tended to have shorter lengths, wider widths, gentler slopes, and greater average bare soil than approaches in the Ridge and Valley region. The differences could be attributed to management different objectives (e.g., intensive, short-rotation pine silviculture management in the Piedmont and extensive long rotation hardwood management in the Ridge and Valley).

Trapped sediment data ranged from 291 to less than $0.01 \mathrm{Mg} \mathrm{ha}^{-1}$ year $^{-1}$, with a mean and median of 20 and 1.44 $\mathrm{Mg} \mathrm{ha}^{-1}$ year $^{-1}$, respectively (fig. 4). All models overpredicted trapped erosion rates at the 75 th quantile, median, and 
Table 1. Descriptive statistics of stream crossing approaches in the Piedmont, Ridge and Valley, and both physiographic regions.

\begin{tabular}{|c|c|c|c|c|c|c|c|}
\hline Region $^{[\mathrm{a}]}$ & Measure & Maximum & $\mathrm{Q}_{75}$ & Mean & Median & $\mathrm{Q}_{25}$ & Minimum \\
\hline \multirow[t]{4}{*}{ Piedmont } & Approach length (m) & 130 & 62.5 & 45.2 & 30.5 & 23.3 & 12.8 \\
\hline & Approach width (m) & 6.40 & 4.57 & 3.82 & 3.66 & 3.20 & 2.13 \\
\hline & Slope $(\%)$ & 16.0 & 8.00 & 6.62 & 6.00 & 4.00 & 2.00 \\
\hline & Bare soil (\%) & 93.8 & 66.3 & 52.0 & 50.0 & 34.4 & 8.00 \\
\hline \multirow[t]{4}{*}{ Ridge and Valley } & Approach length (m) & 427 & 97.5 & 88.2 & 61.7 & 24.0 & 6.10 \\
\hline & Approach width (m) & 3.66 & 3.28 & 3.05 & 3.05 & 2.74 & 2.44 \\
\hline & Slope $(\%)$ & 13.0 & 11.3 & 7.19 & 7.00 & 5.00 & 1.00 \\
\hline & Bare soil (\%) & 42.5 & 28.1 & 19.3 & 14.6 & 10.7 & 1.75 \\
\hline \multirow[t]{4}{*}{ Both regions } & Approach length (m) & 427 & 80.9 & 63.8 & 39.6 & 23.3 & 6.10 \\
\hline & Approach width (m) & 6.40 & 3.66 & 3.48 & 3.35 & 2.74 & 2.13 \\
\hline & Slope $(\%)$ & 16.0 & 8.00 & 6.86 & 7.00 & 4.50 & 1.00 \\
\hline & Bare soil (\%) & 93.8 & 53.8 & 37.9 & 35.0 & 14.6 & 1.75 \\
\hline
\end{tabular}

[a] Twenty-one stream crossing approaches located in the Ridge and Valley region and 16 in the Piedmont region.

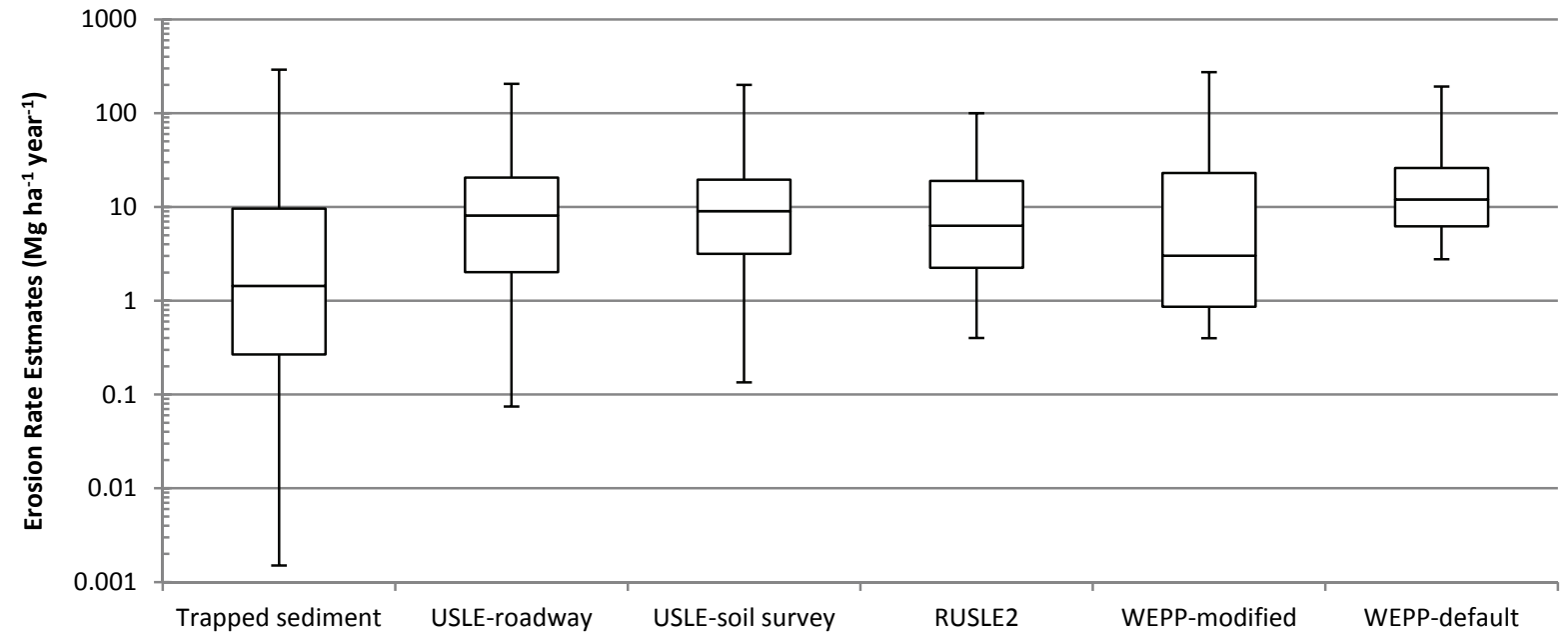

Figure 4. Boxplots of erosion rate estimates for trapped sediment data and each modeling method. Box and whisker plots display first, second, and third quartile and maximum and minimum values. Note the log scale.

25th quantile. At the 75th quantile, model estimates were greater than trapped erosion rates by more than $9 \mathrm{Mg} \mathrm{ha}^{-1}$ year $^{-1}$. At the median, overestimates ranged from 1.59 to $10.6 \mathrm{Mg} \mathrm{ha}^{-1}$ year $^{-1}$. At the 25 th quantile, overestimates were all less than $6 \mathrm{Mg} \mathrm{ha}^{-1}$ year $^{-1}$. These results indicate better model and trapped sediment agreement at lower rather than higher erosion rates. Means of modeled erosion rates deviated from the trapped sediment means by 0.7 to $5.5 \mathrm{Mg} \mathrm{ha}^{-1}$ year $^{-1}$ and displayed high measures of variance and positive skewedness (fig. 4). WEPP-Modified had the closest median estimate to trapped sediment data, followed by RUSLE2, USLE-Roadway, USLE-Soil Survey, and WEPP-Default.

For approaches above the erosion threshold $(>11.2 \mathrm{Mg}$ $\mathrm{ha}^{-1}$ year $^{-1}$ ), all models tended to underpredict erosion rates for all summary statistics. WEPP-Modified was closest to the trapped sediment data at the maximum and mean. WEPP-Default was closest to the trapped sediment data at the 75 th and 25 th quantiles. USLE-Soil Survey had the closest median estimate to trapped sediment data $\left(29.5 \mathrm{Mg} \mathrm{ha}^{-1}\right.$ year $\left.^{-1}\right)$. For approaches below the erosion threshold, all models tended to overpredict erosion rates for all summary statistics. WEPP-Modified was furthest from the trapped sediment data at the maximum but closest at the median, 75th, and 25 th quantiles. WEPP-Modified had the closest modeled estimates to over half of the approaches with erosion rates below the threshold. USLE-Roadway had the closest mean estimate to trapped sediment data below the threshold, albeit a $7.86 \mathrm{Mg} \mathrm{ha}^{-1}$ year $^{-1}$ difference.

The spread between each modeling method and the trapped sediment data was relatively low at the mean and median, likely because $78 \%$ of the stream crossing approaches produced low erosion values $\left(<11.2 \mathrm{Mg} \mathrm{ha}^{-1}\right.$ year $\left.^{-1}\right)$. Each modeling method estimated erosion rates within the range of the trapped sediment data (fig. 4). WEPP-Default had the highest mean magnitude of error at $32.4 \mathrm{Mg} \mathrm{ha}^{-1}$ year $^{-1}$, where the magnitude of error is calculated as the absolute value of the difference between the model prediction and the trapped sediment data. The second highest mean magnitude of error was for WEPP-Modified at $29.3 \mathrm{Mg} \mathrm{ha}^{-1}$ year $^{-1}$. The third and fourth highest mean magnitudes of error were for USLE-Soil Survey and USLE-Roadway at 24.8 and $24.4 \mathrm{Mg} \mathrm{ha}^{-1}$ year $^{-1}$, respectively. The lowest mean magnitude of error was for RUSLE2 at $22.9 \mathrm{Mg} \mathrm{ha}^{-1}$ year ${ }^{-1}$.

We compared all model erosion estimates to the trapped sediment data using the Kruskal-Wallis statistical test (Zar, 2010). The Kruskal-Wallis statistical test indicated significant differences between the trapped sediment data and model estimates $(p<0.001)$. The results of the Wilcoxon comparison test showed significant differences between the trapped sediment data and USLE-Roadway ( $\mathrm{p} \leq 0.019$ ), USLE-Soil Survey ( $p \leq 0.005)$, RUSLE2 ( $\mathrm{p} \leq 0.010)$, and WEPP-Default ( $\mathrm{p} \leq 0.001)$. WEPP-Modified was not signif- 
icantly different from the trapped sediment data $(\mathrm{p} \geq 0.107)$; therefore, WEPP-Modified performed better than the other modeling methods examined.

\section{LINEAR RELATIONSHIPS}

All models had coefficients of determination $\left(\mathrm{R}^{2}\right)$ below 0.5 (fig. 5). Weak linear relationships between the trapped sediment data and each model indicated poor overall model performances on haul road stream crossing approaches. USLE-Soil Survey had the strongest linear relationship with the trapped sediment data $\left(\mathrm{R}^{2}=0.21\right)$, followed by USLERoadway $\left(\mathrm{R}^{2}=0.16\right)$. The RUSLE2, WEPP-Modified, and WEPP-Default models had coefficients of determinations less than 0.10. Overall, the linear relationships between the trapped sediment data and model estimates did not justify additional exploration of these relationships. These relationships clearly indicate the need for additional development or improvement of models for prediction of the erosion associated with stream crossing approaches.

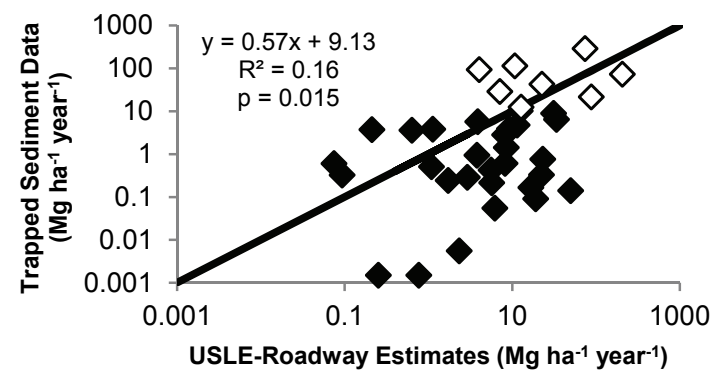

(a)

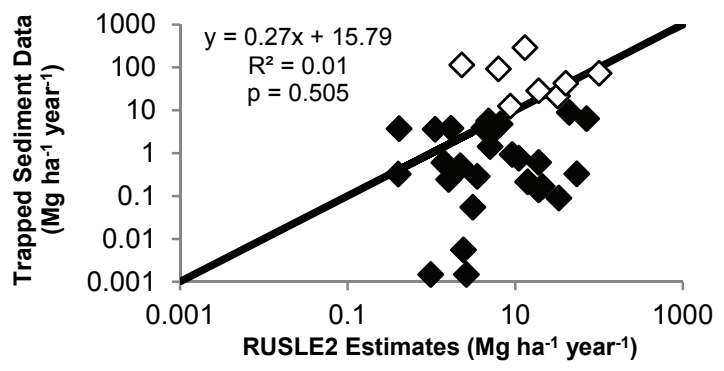

\section{Percent Agreement between Measured}

DATA AND MODELED ESTIMATES

The stream crossing approaches were ranked into erosion rate categories (very low, low, moderate, and high) according to trapped sediment erosion rates (table 2). For the 37 stream crossing approaches, 54\% were very low, followed by low (27\%), high (11\%), and moderate (8\%). All soil erosion models had the best agreement at the very low level. WEPP-Modified correctly identified $85 \%$ of the very low approaches, followed by USLE-Roadway (75\%), RUSLE2 (65\%), USLE-Soil Survey (60\%), and WEPP-Default $(50 \%)$. At the low level, all models performed slightly worse than at the very low level. WEPP-Modified and USLE-Roadway each correctly identified $70 \%$ of the low approaches, followed by RUSLE2 (60\%), USLE-Soil Survey $(60 \%)$, and WEPP-Default (50\%). All soil erosion models inadequately categorized approaches in the moderate and high erosion rate categories. Of the seven approaches in these two categories, USLE-Soil Survey correctly identified three, while the three remaining models correctly identified only two approaches. Overall, WEPP-Modified correctly identified $70 \%$ of erosion-categorized approaches, followed

(c)

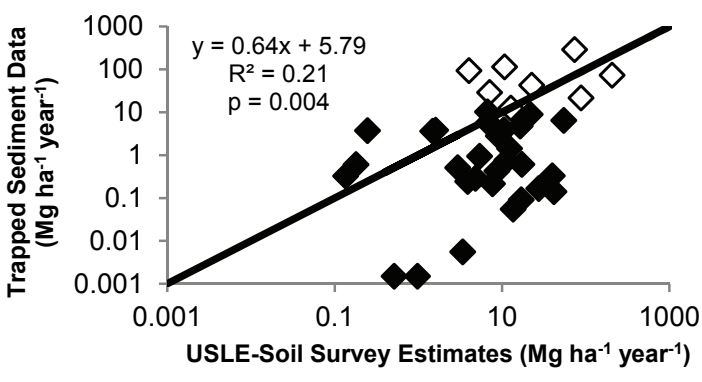

(b)

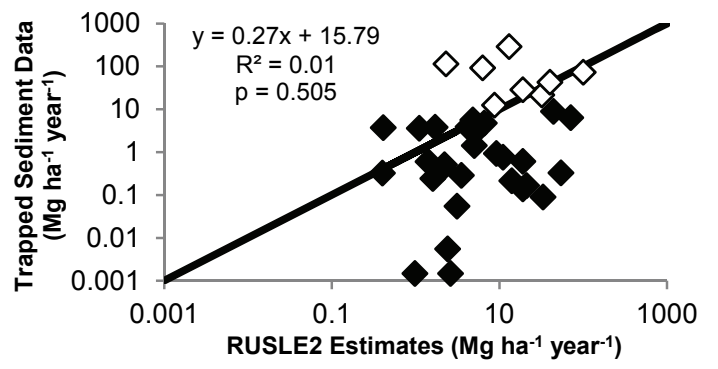

(d)

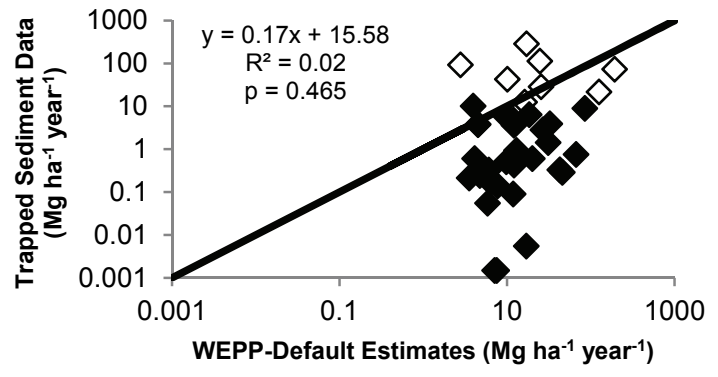

(e)

Figure 5. Linear relationship between trapped sediment data and (a) USLE-Roadway, (b) USLE-Soil Survey, (c) RUSLE2, (d) WEPP-Modified, and (e) WEPP-Default estimates. Filled and hollow data points represent trapped sediment values below and above the $11.2 \mathrm{Mg} \mathrm{ha}^{-1} \mathrm{year}^{-1} \mathrm{thresh}^{-}$ old, respectively. Data above and below the 1:1 line indicate model underestimations and overestimations, respectively. 
Table 2. Percentage of correct BMP category identifications by each soil erosion model.

\begin{tabular}{|c|c|c|c|c|c|c|c|c|}
\hline \multirow[b]{2}{*}{$\begin{array}{c}\text { Erosion Rate } \\
\text { Category }\end{array}$} & \multirow{2}{*}{$\begin{array}{c}\text { Erosion Rate } \\
\text { Range } \\
\left(\mathrm{Mg} \mathrm{ha}^{-1} \text { year }^{-1}\right)\end{array}$} & \multirow[b]{2}{*}{$n$} & \multirow{2}{*}{$\begin{array}{c}\text { Trapped Sediment } \\
\text { Data Range } \\
\left(\mathrm{Mg} \mathrm{ha}^{-1} \text { year }^{-1}\right)\end{array}$} & \multicolumn{5}{|c|}{ Correct BMP Category Placement $(\%)$ by Model ${ }^{[\mathrm{a}]}$} \\
\hline & & & & $\begin{array}{c}\text { USLE- } \\
\text { Roadway }\end{array}$ & $\begin{array}{c}\text { USLE- } \\
\text { Soil Survey }\end{array}$ & RUSLE2 & $\begin{array}{l}\text { WEPP- } \\
\text { Modified }\end{array}$ & $\begin{array}{l}\text { WEPP- } \\
\text { Default }\end{array}$ \\
\hline Very low & $<10$ & 20 & $<0.1$ to 2.9 & 75 & 60 & 65 & $85^{[\mathrm{b}]}$ & 50 \\
\hline Low & 10.1 to 25 & 10 & 3.6 to 12.6 & $70^{[\mathrm{b}]}$ & 50 & 60 & $70^{[\mathrm{b}]}$ & 40 \\
\hline Moderate & 25.1 to 50 & 3 & 21.8 to 43.1 & 0 & $33^{[\mathrm{b}]}$ & $33^{[b]}$ & 0 & $33^{[\mathrm{b}]}$ \\
\hline High & $>50.1$ & 4 & 73.6 to 290.7 & $50^{[\mathrm{b}]}$ & $50^{[\mathrm{b}]}$ & 25 & $50^{[\mathrm{b}]}$ & 25 \\
\hline All categories & - & 37 & $<0.1$ to 290.7 & 65 & 54 & 57 & $70^{[\mathrm{b}]}$ & 43 \\
\hline
\end{tabular}

[a] BMP categories based on Nolan et al. (2015) and Brown et al. (2013).

[b] Greatest percent correct within the row for each BMP category.

by USLE-Roadway (65\%), RUSLE2 (57\%), USLE-Soil Survey (54\%), and WEPP-Default (43\%) (table 2).

Regarding the trapped sediment data from the 37 stream crossing approaches, two approaches collected more than $100 \mathrm{Mg} \mathrm{ha}^{-1}$ year $^{-1}$, two collected between 99 and $50 \mathrm{Mg}$ $\mathrm{ha}^{-1}$ year $^{-1}$, five collected between 49 and $10 \mathrm{Mg} \mathrm{ha}^{-1}$ year $^{-1}$, ten collected between 9.9 and $1.0 \mathrm{Mg} \mathrm{ha}^{-1}$ year $^{-1}$, and 18 collected less than $1 \mathrm{Mg} \mathrm{ha}^{-1}$ year $^{-1}$. WEPP-Modified and RUSLE2 had the highest percent agreement (32\%), where percent agreement is the frequency with which the modeled estimates were within the tolerance ranges of the trapped sediment data. USLE-Roadway and USLE-Soil Survey had the next highest percent agreement (27\%), followed by WEPP-Default (11\%). For WEPP-Default, $67 \%$ of estimates were above the tolerance range, while fewer exceedances were observed for WEPP-Modified (49\%), RUSLE2 (54\%), USLE-Roadway (57\%), and USLE-Soil Survey (59\%). The frequency of estimates below the tolerance ranges was much less for all models. WEPP-Modified most frequently underestimated trapped sediment values $(19 \%)$, followed by USLE-Roadway (16\%), USLE-Soil Survey (14\%), RUSLE2 (14\%), and WEPP-Default (14\%).

\section{Contingency Table Assessment}

Model performance is seldom evaluated by a single metric; thus, we calculated five model performance metrics (table 3), as provided by Bennett et al. (2013). The five selected metrics were accuracy, bias score, probability of detection, false alarm ratio, and success index. All five metrics require a "trigger". We established a trigger (Bennett et al., 2013) rate of $11.2 \mathrm{Mg} \mathrm{ha}^{-1}$ year $^{-1}$ for the 37 stream crossing approaches. We determined that 29 approaches had trapped erosion rates below this trigger, while eight approaches had erosion rates greater than the trigger.

Model accuracy ranged from 0.54 to 0.78 (table 3 ). WEPP-Modified had the best accuracy $(0.78)$, followed by RUSLE2 (0.70), USLE-Roadway (0.68), USLE-Soil Survey (0.65), and WEPP-Default (0.54). Bias scores (Bennett et al., 2013) indicate whether the model will underestimate (bias $<1$ ) or overestimate (bias $>1$ ). All models tended to overestimate more frequently than underestimate in instances where trapped sediment rates were less than the trigger.
WEPP-Default had the highest bias score (2.38), followed by USLE-Soil Survey (2.13), USLE-Roadway (1.75), RUSLE2 (1.63), and WEPP-Modified (1.25). The probability of detection rate (Bennett et al., 2013) was greatest for WEPP-Default and USLE-Soil Survey (0.75), while the other three models had equivalent detection rates (0.63). False alarm ratios ranged from 0.50 to 0.79 . WEPP-Default most frequently overestimated erosion rates below the trigger (0.79), followed by USLE-Soil Survey (0.65), USLERoadway (0.64), RUSLE2 (0.62), and WEPP-Modified (0.50). The success index was greatest for WEPP-Modified (0.73), followed by USLE-Soil Survey (0.69), RUSLE2 (0.67), USLE-Roadway (0.66), and WEPP-Default (0.62) (table 3 ). Based on these metrics of model performance, WEPP-Modified was the "best" model in four of the five metrics (accuracy, bias score, false alarm ratio, and success index), and WEPP-Modified was second best in the probability of detection. However, it is important to note that WEPP-Default was the poorest performer based on these five metrics and was the "worst" performing model in all other metrics of model performance.

\section{OVERALl Model RANKINGS}

Another objective of the study was to evaluate the performance of the erosion models with different levels of fieldinformed detail by comparing model simulations to trapped sediment measurements. We used twelve model performance metrics to compare the ability of the five models for prediction of erosion from forest road stream crossing approaches. Table 4 provides the findings from the nonparametric analysis and model rankings for the remaining eleven model performance metrics. Overall, USLE-Roadway, USLE-Soil Survey, and RUSLE2 had similar cumulative rankings $(26,30$, and 26 , respectively), where the best possible ranking could be 11 and the worst potential ranking could be 55. However, WEPP-Modified had the best overall ranking with a cumulative score of 15 and was the "best" model for nine of the eleven metrics. Kruskal-Wallis nonparametric analyses revealed that WEPP-Modified sediment estimates were not significantly different from the trapped sediment data ( $\mathrm{p} \geq 0.107)$, and WEPP-Modified better approximated the trapped sediment volumes than did all other

Table 3. Model performance metrics that compare trapped sediment data with model estimates.

\begin{tabular}{|c|c|c|c|c|c|}
\hline Estimation Method & Accuracy $^{[\mathrm{a}]}$ & Bias Score $^{[\mathrm{a}]}$ & Probability of Detection $^{[\mathrm{a}]}$ & False Alarm Ratio $^{[\mathrm{b}]}$ & Success Index ${ }^{[\mathrm{a}]}$ \\
\hline USLE-Roadway & 0.68 & 1.75 & 0.63 & 0.64 & 0.66 \\
\hline USLE-Soil Survey & 0.65 & 2.13 & 0.75 & 0.65 & 0.69 \\
\hline RUSLE2 & 0.70 & 1.63 & 0.63 & 0.62 & 0.67 \\
\hline WEPP-Modified & 0.78 & 1.25 & 0.63 & 0.50 & 0.73 \\
\hline WEPP-Default & 0.54 & 2.38 & 0.75 & 0.79 & 0.62 \\
\hline
\end{tabular}

\footnotetext{
[a] Ideal value $=1$.
}

[b] Ideal value $=0$. 
Table 4. Model rankings for twelve performance metrics $(1=$ best performing model and $5=$ poorest performing model; identical numbers indicate equal performance).

\begin{tabular}{|c|c|c|c|c|c|}
\hline \multirow[b]{2}{*}{ Performance Metric } & \multicolumn{5}{|c|}{ Model } \\
\hline & USLE-Roadway & USLE-Soil Survey & RUSLE2 & WEPP-Modified & WEPP-Default \\
\hline Descriptive: All & 2 & 4 & 3 & 1 & 4 \\
\hline Descriptive: Above & 2 & 2 & 3 & 1 & 1 \\
\hline Descriptive: Below & 1 & 2 & 2 & 1 & 2 \\
\hline Linear relationships & 2 & 1 & 3 & 3 & 3 \\
\hline Correctly placed erosion categories & 2 & 4 & 3 & 1 & 5 \\
\hline Percent agreement with tolerable error ranges & 2 & 2 & 1 & 1 & 3 \\
\hline Contingency table: Accuracy & 3 & 4 & 2 & 1 & 5 \\
\hline Contingency table: Bias score & 3 & 4 & 2 & 1 & 5 \\
\hline Contingency table: Probability of detection & 2 & 1 & 2 & 2 & 1 \\
\hline Contingency table: False alarm ratio & 3 & 4 & 2 & 1 & 5 \\
\hline Contingency table: Success index & 4 & 2 & 3 & 1 & 5 \\
\hline Nonparametric analysis & $\begin{array}{c}\text { Significantly } \\
\text { different }\end{array}$ & $\begin{array}{c}\text { Significantly } \\
\text { different }\end{array}$ & $\begin{array}{c}\text { Significantly } \\
\text { different }\end{array}$ & $\begin{array}{c}\text { Not significantly } \\
\text { different }\end{array}$ & $\begin{array}{c}\text { Significantly } \\
\text { different }\end{array}$ \\
\hline Total cumulative score & 26 & 30 & 26 & 15 & 39 \\
\hline
\end{tabular}

models. In contrast, WEPP-Default was found to have the highest cumulative score, which indicated that this model was the least desirable of the five models that we evaluated.

\section{DISCUSSION}

The overall goal of this project was to evaluate the sediment delivery potential from forest stream crossings and compare results to model estimates. Compared to the trapped sediment erosion data, all soil erosion models tended to overestimate median sediment values. However, all soil erosion models frequently performed sufficiently well to place the erosion estimates into the correct erosion categories. This proper erosion category placement corresponds well with other forest road studies in Virginia that compared measured erosion with modeled estimates of erosion. Brown et al. (2013) measured and modeled sediment delivery from stream crossing approaches and reported measured sediment delivery rates of 10 to $16 \mathrm{Mg} \mathrm{ha}^{-1}$ year $^{-1}$ for graveled approaches and 34 to $287 \mathrm{Mg} \mathrm{ha}^{-1}$ year $^{-1}$ for bare soil approaches. They concluded that both USLE-Forest and WEPP performed well in identifying problem road approaches, but WEPP performed better than USLE-Forest. Wade et al. (2012) reported mean erosion rates of less than $32 \mathrm{Mg} \mathrm{ha}^{-1}$ year $^{-1}$ for bladed skid trails with seed, mulch, or slash closure BMPs and $138 \mathrm{Mg} \mathrm{ha}^{-1}$ year $^{-1}$ for bare soil with water bar control treatments. Similarly, USLE-Forest, RUSLE2, and WEPP adequately ranked soil erosion rates for trails with and without BMPs. However, WEPP did not perform as well as RUSLE2 and USLE-Forest. Sawyers et al. (2012) compared trapped sediment data to WEPP and USLE-Forest for overland skid trails and found that WEPP performed better than USLE-Forest, but both models generally agreed with trapped sediment data. Our results and those from other similar studies clearly indicate that forest operations with inadequate BMPs or poor maintenance have potential to produce excessive erosion, yet BMPs often reduce sediment yield to the stream to amounts similar to geologic rates (Patric, 1976). Additionally, versions of the USLE and WEPP models perform sufficiently well to identify problem areas but have varying results in adequately quantifying sediment from forest roads.

Our trapped sediment data indicated that erosion rates on haul road stream crossing approaches vary from negligible to hundreds of $\mathrm{Mg} \mathrm{ha}^{-1}$ year $^{-1}$. Four of the 37 stream crossing approaches eroded at high rates $\left(>50.1 \mathrm{Mg} \mathrm{ha}^{-1}\right.$ year $\left.^{-1}\right)$ (table 2). These approaches had evidence of water control; however, the water control structures were no longer effectively controlling stormwater runoff and were directly connected to the stream channel. Approaches categorized as high would benefit from road maintenance and would require extensive corrective BMPs to control erosion. Croke et al. (2005) described direct connectivity in their study as occurring when channels or gullies formed, leading directly to stream channels, typically below cross drains with excessive contributing areas. Direct connections to stream channels in this study stemmed from the road surface. The combination of the four most eroded approaches contributed $573 \mathrm{Mg} \mathrm{ha}^{-1}$ year $^{-1}$, which is 3.4 times greater than the sum of all erosion from the remaining 33 stream crossing approaches. Nolan et al. (2015) used USLE-Forest to estimate erosion at haul road stream crossings across Virginia and found that erosion rates were 13 times greater for sites with inadequate BMPs as compared to sites with correctly implemented BMPs.

The general WEPP model incorporates numerous parameters that are intended to reflect the environment, such as climate, hydrology and water budget, plant growth, soil composition, and various forestry and agricultural operations (Amore et al., 2004). The intention of WEPP was to succeed the USLE method, as the demand for greater accuracy increased (Flanagan et al., 2007). Numerous researchers have found that WEPP performed well for agricultural (Abaci and Papanicolaou, 2009), rangeland (Simanton et al., 1991), construction (Moore et al., 2007), and various forest operations (Forsyth et al., 2006; Dun et al., 2009; Wade et al., 2012; Elliot, 2013), yet considerable modifications to input parameters and calibration are generally required to achieve satisfactory model performance. Even when model estimates are consider satisfactory, uncertainty and equifinality remain an issue (Brazier et al., 2000). Brown et al. (2016) evaluated the uncertainty in WEPP estimates of sediment yield from forest road stream crossing approaches and concluded that WEPP's utility for estimating BMP effectiveness is limited to predicting relative differences in vastly different BMP treatments. Additionally, they were unable to confidently recommend parameter ranges specific to bare or gravel surface treatments for forest road approaches. However, our results for most model performance metrics and statistical 
analyses indicated that WEPP-Modified had the greatest potential of the models evaluated to estimate soil erosion for forest road stream crossing approaches. The reasons why WEPP may have performed better than the empirical models include greater model specificity (e.g., incorporation of observed rainfall, soil, road dimension, ditch, and vegetative parameter details). Greater model specificity is known to lead to greater uncertainty and equifinality (Brazier et al., 2000; Brown et al., 2016). Brazier et al. (2000) evaluated WEPP performance on two data sets and concluded that there was significant uncertainty in WEPP's input parameters and model structure. Skaugset et al. (2011) found that WEPP and RUSLE2 overestimated soil erosion on roads in the Pacific Northwest region of the U.S. by 2 to 8 times because the road surface hydrology was not adequately represented by the models. They suggested that further consideration of the hydrology component is necessary for forest roads. In the current study, we were able to incorporate observed precipitation data into WEPP-Modified, which likely led to better model performance compared to the other tested models. The ability to increase the specificity of physical models is promising for the future of soil erosion estimation, but better, easier, and enhanced methods are needed to measure the parameters that drive these models. Oreskes et al. (1994) identified parameter scale as an important consideration of model uncertainty. They stated that multiple scales are used in the development model parameters, which affect their relationships and are always uncertain.

WEPP-Default had the lowest potential to model soil erosion as compared to the other models in this study. Modified versions of WEPP have been successfully applied in previous studies without characterization of the climate data (Liu et al., 1997; Tiwari et al., 2000). Tiwari et al. (2000) applied WEPP in an uncalibrated method and compared model estimates with USLE and RUSLE. Each model had Nash-Sutcliffe model efficiency values greater the 0.71 , which indicates exceptional model performance. Wade et al. (2012) concluded that the greatest strength and weakness of WEPP is its flexibility of parameters, and that the default parameters may not be suited for a particular purpose. Forestry practitioners require a soil erosion model with readily attainable parameters to estimate site-specific road conditions. Therefore, WEPP is better suited for researchers and government agencies that have the capability to measure the most influential parameter data. This suggests that additional sensitivity analysis is needed to better understand the influences of default parameters for forest roads within WEPP. Erosion models are representations of scientific hypothesis and therefore guide future research. The primary value of WEPP, USLE, and RUSLE2 is heuristic (Oreskes et al., 1994). Incorporating physical models such as WEPP into BMP inspections and assessments of management alternatives would be difficult because of the number of parameters and the calibration required.

USLE is the most widely used soil erosion model for a variety of sites and management conditions (Kinnell, 2010). The different levels of parameter detail within USLE-Roadway, USLE-Soil Survey, and RUSLE2 did not improve the model estimates when compared to the trapped sediment data $(p<0.10)$. Sheridan et al. (2008) simulated rainfall over forest roads, compared mapped erosivity values with observed data, and found that observed data for model $K$ values did not provide greater accuracy than modeled erosivity values. Using the soil particle size data to calculate the erosivity factor ( $K$ values) in USLE-Roadway and RUSLE2 marginally improved the model estimates over USLE-Soil Survey, which simply used $K$ values from the soil survey for site subsoils. USLE-Soil Survey was the easiest and simplest of the methods evaluated to estimate soil erosion. USLE-Soil Survey is a useful method for field comparisons as compared to RUSLE2, which requires computer access (Christopher and Visser, 2007). However, RUSLE2 offers a database that allows users to download and store a variety of soil, climate, and management files that can be used repeatedly thereafter. Compared to USLE-Forest, RUSLE2 allows users to incorporate more complex surfaces, slopes, and soils and observed precipitation files. However, WEPP appears to have greater potential than RUSLE2 to quantify sediment above 11.2 $\mathrm{Mg} \mathrm{ha}^{-1}$ year $^{-1}$.

The empirical models in this study did not perform well in quantifying sediment at stream crossings. Empirical models estimate erosion over a long-term (10+ years) continuous basis and were not intended to be applied to single events or short-term estimates, as in our study. They continue to be applied in such studies because of their ease of use and underlying theory. One of the limitations of USLE and its modifications for forest road erosion modeling is that its development was based on agricultural soils. Road surfaces are highly compacted and have variable surface roughness ratios depending on traffic level (Sheridan and Noske, 2007). Traffic level and specific BMPs are not directly considered in USLE models but are important factors in soil erosion from forest roads (Reid and Dunn, 1984; Fu et al., 2010). Croke and Nethery (2006) reported that RUSLE overestimated soil loss by nearly an order of magnitude during a 10 -year storm event on skid trails. Furthermore, they concluded that further research on the major erosion factors and subfactors is necessary for RUSLE to be applicable to forest road conditions. It is important to note that models give results within the range of conditions for which they were developed, and they therefore have different levels of utility depending on the intended use and available data.

We also used this project as an opportunity to assess the utility of the models for identifying stream crossing approaches that reflected different categories of BMP implementation. For example, what level of erosion might occur for forest roads that have either poor or excellent levels of BMP implementation? This type of information could be useful for state agency personnel attempting to strategically inspect forest harvest operations or for forest managers who are tasked with ensuring BMP implementation with limited resources. Furthermore, these models could have utility for instructing students in the general effects of BMPs on stream sediment. Ideally, a model would provide good estimates and be relatively straightforward to use. Unfortunately, the best model (WEPP-Modified) requires extensive parameter adjustments before it can perform well, and such adjustments require extensive knowledge of erosion processes, of the WEPP model, and of how WEPP responds to adjustments. Such adjustments are simply beyond the time con- 
straints and qualifications of many organizations, yet WEPP-Default does not appear to be an acceptable substitute. Commonly, forest managers do not have sufficient time or expertise to evaluate and modify model components and change default settings. Therefore, the standard WEPP model is often too onerous to use for simply identifying situations that may require additional BMPs. We evaluated the benefits and problems associated with the three remaining models and concluded that USLE-Forest (i.e., USLE-Soil Survey and USLE-Roadway) is the simplest and most timeefficient model, while it provided the second best ability to place erosion values within the correct BMP category (table 2).

\section{Conclusions}

After several decades of forest BMP research, there are still numerous information gaps that confound our ability to accurately assess the impact of forest BMPs on stream sediment. Models could help us fill these gaps in an expeditious manner. Research indicates that forest BMPs generally minimize erosion from forest operations, yet forest stream crossings may have higher sediment delivery potential than all other forest operations. Thus, we evaluated the performance of five variations of three common erosion models for stream crossing approaches. Despite the importance of stream crossings, few research projects have evaluated the effects of stream crossings across a range of erosion potentials, and few projects have evaluated the use of erosion models for stream crossings. Our major conclusions are:

- The soil erosion models evaluated in this study estimated erosion and sediment delivery within $5 \mathrm{Mg} \mathrm{ha}^{-1}$ year $^{-1}$ for most approaches with erosion rates less than 11.2 $\mathrm{Mg} \mathrm{ha}^{-1}$ year $^{-1}$, while model estimates varied widely for approaches that eroded above $11.2 \mathrm{Mg} \mathrm{ha}^{-1}$ year $^{-1}$. Based on the results from 12 evaluations of model performance, WEPP-Modified consistently ranked higher than the other models, yet its performance in estimating erosion above $11.2 \mathrm{Mg} \mathrm{ha}^{-1}$ year- $^{-1}$ clearly needs additional improvement. WEPP requires input parameters that are not readily available and easily measured, yet modifications to the input parameters are necessary to fit the site conditions. Using the default parameters to simulate erosion (WEPP-Default) ranked worst in $75 \%$ of the model performance metrics compared to all other models. WEPP-Default overpredicted erosion by $\geq 5 \mathrm{Mg} \mathrm{ha}^{-1}$ year-1 for $82 \%$ of approaches with erosion rates less than $11.2 \mathrm{Mg} \mathrm{ha}^{-1}$ year $^{-1}$ and correctly placed only $43 \%$ of erosion estimates into the appropriate erosion category.

- Additional field evaluations and improved erosion models are needed for stream crossings. Sensitivity analyses are needed to better understand the influences of default parameters for forest roads within the WEPP and USLE models.

- Two models, WEPP-Modified and USLE-Roadway, correctly placed $\geq 70 \%$ of approaches into the very low and low erosion categories. Due to the complexity of input parameters and scaling issues with WEPP-Mod- ified, USLE-Roadway may be a more practical choice for many forest managers and agency personnel. Using the soil survey to obtain $K$ values may be misleading for roads because road construction changes the soil composition. Determining the soil texture in the field or laboratory will better characterize the site.

\section{ACKNOWLEDGEMENTS}

Funding for this work was provided in part by the National Council for Air and Stream Improvement, Inc. (NCASI), the McIntire-Stennis Program of the USDA National Institute of Food and Agriculture, and the Virginia Tech Forest Operations and Business Research Cooperative. WestRock Corporation and the Virginia Tech Department of Forest Resources and Environmental Conservation provided logistical support. The U.S. Forest Service provided study sites in the George Washington and Jefferson National Forest.

\section{REFERENCES}

Abaci, O., \& Papanicolaou, A. N. (2009). Long-term effects of management practices on water-driven soil erosion in an intense agricultural subwatershed: Monitoring and modeling. Hydrol. Proc., 23(19), 2818-2837. http://dx.doi.org/10.1002/hyp.7380

Amore, E., Modica, C., Nearing, M. A., \& Santoro, V. C. (2004). Scale effect in USLE and WEPP application for soil erosion computation from three Sicilian basins. J. Hydrol., 293(1), 100114. http://dx.doi.org/10.1016/j.jhydrol.2004.01.018

Anderson, C. J., \& Lockaby, B. G. (2011). Research gaps related to forest management and stream sediment in the United States. Environ. Mgmt., 47(2), 303-313. http://dx.doi.org/10.1007/s00267-010-9604-1

Aust, W. M., Bolding, M. C., \& Barrett, S. M. (2015). Best management practices for low-volume forest roads in the Piedmont region. Transport. Res. Record: J. Transport. Res. Board, 2472, 51-55. http://dx.doi.org/10.3141/2472-06

Aust, W. M., Carroll, M. B., Bolding, M. C., \& Dolloff, C. A. (2011). Operational forest stream crossings effects on water quality in the Virginia Piedmont. Southern J. Appl. Forestry, 35(3), 123-130.

Aust, W. M., Shaffer, R. M., \& Burger, J. A. (1996). Benefits and costs of forestry best management practices in Virginia.

Southern J. Appl. Forestry, 20(1), 23-29. https://doi.org/10.3141/2472-06

Bennett, N. D., Croke, B. F., Guariso, G., Guillaume, J. H. A., Hamilton, S. H., Jakeman, A. J., ... Andreassian, V. (2013). Characterising performance of environmental models. Environ. Model. Software, 40, 1-20. http://dx.doi.org/10.1016/j.envsoft.2012.09.011

Boston, K. (2012). Impact of the Ninth Circuit Court ruling (Northwest Environmental Defense Center v. Brown) regarding forest roads and the Clean Water Act. J. Forestry, 110(6), 344346. http://dx.doi.org/10.5849/jof.11-069

Brazier, R. E., Beven, K. J., Freer, J., \& Rowan, J. S. (2000). Equifinality and uncertainty in physically based soil erosion models: Application of the GLUE methodology to WEPP - the Water Erosion Prediction Project - for sites in the UK and USA. Earth Surf. Proc. Landforms, 25(8), 825-845.

http://dx.doi.org/10.1002/1096-9837(200008)25:8<825::AIDESP101>3.0.CO;2-3

Brown, K. R., Aust, W. M., \& McGuire, K. J. (2013). Sediment delivery from bare and graveled forest road stream crossing approaches in the Virginia Piedmont. Forest Ecol. Mgmt., 310, 
836-846. http://dx.doi.org/10.1016/j.foreco.2013.09.031

Brown, K. R., McGuire, K. J., Hession, W. C., \& Aust, W. M. (2016). Can the Water Erosion Prediction Project model be used to estimate best management practice effectiveness from forest roads? J. Forestry, 114(1), 17-26.

http://dx.doi.org/10.5849/jof.14-101

Christopher, E. A., \& Visser, R. (2007). Methodology for evaluating post-harvest erosion risk for the protection of water quality. New Zealand J. Forestry, 52(2), 20-25.

Croke, J., \& Nethery, M. (2006). Modelling runoff and soil erosion in logged forests: Scope and application of some existing models. Catena, 67(1), 35-49. http://dx.doi.org/10.1016/j.catena.2006.01.006

Croke, J., Mockler, S., Fogarty, P., \& Takken, I. (2005). Sediment concentration changes in runoff pathways from a forest road network and the resultant spatial pattern of catchment connectivity. Geomorphology, 68(3-4), 257-268. http://dx.doi.org/10.1016/j.geomorph.2004.11.020

Dissmeyer, G. E., \& Foster, G. R. (1984). A guide for predicting sheet and rill erosion on forest land. General Tech. Publ. R8-TP 6. Washington, DC: USDA Forest Service.

Dun, S., Wu, J. Q., Elliot, W. J., Robichaud, P. R., Flanagan, D. C., Frankenberger, J. R., ... Xu, A. C. (2009). Adapting the Water Erosion Prediction Project (WEPP) model for forest applications. J. Hydrol., 366(1-4), 46-54. http://dx.doi.org/10.1016/j.jhydrol.2008.12.019

Edwards, P. J., Schoonover, J. E., \& Williard, K. W. J. (2015). Guiding principles for management of forested, agricultural, and urban watersheds. J. Contemp. Water Res. Educ., 154(1), 60-84. http://dx.doi.org/10.1111/j.1936-704X.2015.03188.x

Elliot, W. J. (2000). Roads and other corridors. In E. George (Ed.), Drinking water from forests and grasslands: A synthesis of the scientific literature (pp. 85-101). Asheville, NC: USDA Forest Service, Southern Research Station.

Elliot, W. J. (2004). WEPP internet interfaces for forest erosion prediction. J. American Water Resour. Assoc., 40(2), 299-309. http://dx.doi.org/10.1111/j.1752-1688.2004.tb01030.x

Elliot, W. J. (2013). Erosion processes and prediction with WEPP technology in forests in the northwestern U.S. Trans. ASABE, 56(2), 563-579. http://dx.doi.org/10.13031/2013.42680

Elliot, W. J., \& Hall, D. E. (1997). Water erosion prediction project (WEPP) forest applications. General Tech. Publ. Ogden, UT: USDA Forest Service, Intermountain Research Station.

Elliot, W. J., Foltz, R. B., \& Luce, C. H. (1995). Validation of Water Erosion Prediction Project (WEPP) model for lowvolume forest roads. In Proc. 6th Intl. Conf. Low-Volume Roads (pp. 178-186). Washington, DC: National Academy Press.

EPA. (2003). Environmental Defense Center v. U.S. EPA. 344 F.3d 832. United States Court of Appeals for the Ninth Circuit. Retrieved from https://law.resource.org/pub/us/case/reporter/F3/344/344.F3d.83 2.00-70822.00-70734.00-70014.html

EPA. (2005). National management measures to control nonpointsource pollution from forestry. EPA-841-B-05-001. Washington, DC: U.S. Environmental Protection Agency, Office of Water.

EPA. (2012). Revisions to stormwater regulations to clarify that an NPDES permit is not required for stormwater discharges from logging roads. Federal Register, 77(236), 72970-72975. Washington, DC: U.S. Environmental Protection Agency.

EPA. (2015). Notice of opportunity to provide information on existing programs that protect water quality from forest road discharges. Federal Register, 80(217), 69653-69660. Washington, DC: U.S. Environmental Protection Agency.

Flanagan, D. C., Frankenberger, J. R., \& Ascough II, J. C. (2012). WEPP: Model use, calibration, and validation. Trans. ASABE, 55(4), 1463-1477. http://dx.doi.org/10.13031/2013.42254
Flanagan, D. C., Gilley, J. E., \& Franti, T. G. (2007). Water Erosion Prediction Project (WEPP): Development history, model capabilities, and future enhancements. Trans. ASABE, 50(5), 1603-1612. https://doi.org/10.13031/2013.23968

Foltz, R. B., Copeland, N. S., \& Elliot, W. J. (2009). Reopening abandoned forest roads in northern Idaho, U.S.: Quantification of runoff, sediment concentration, infiltration, and interrill erosion parameters. J. Environ. Mgmt., 90(8), 2542-2550. http://dx.doi.org/10.1016/j.jenvman.2009.01.014

Forsyth, A. R., Bubb, K. A., \& Cox, M. E. (2006). Runoff, sediment loss, and water quality from forest roads in a southeast Queensland coastal plain Pinus plantation. Forest Ecol. Mgmt., 221(1-3), 194-206. http://dx.doi.org/10.1016/j.foreco.2005.09.018

Fu, B., Newham, L. T., \& Ramos-Scharron, C. E. (2010). A review of surface erosion and sediment delivery models for unsealed roads. Environ. Model. Software, 25(1), 1-14. http://dx.doi.org/10.1016/j.envsoft.2009.07.013

Gee, G. W., \& Or, D. (2002). Particle-size analysis. In Methods of soil analysis: Part 4. Physical methods (pp. 278-284). Madison, WI: SSSA.

Grossman, R. B., \& Reinsch, T. G. (2002). Bulk density and linear extensibility, core method. In Methods of soil analysis: Part 4. Physical methods (pp. 207-210). Madison, WI: SSSA.

Gucinski, H., Furniss, M. J., Ziemer, R. R., \& Brookes, M. H. (2001). Forest roads: A synthesis of scientific information. Gen. Tech. Rep. PNW-GTR-509. Portland, OR: USDA Forest Service, Pacific Northwest Research Station.

Ice, G. (2004). History of innovative best management practice development and its role in addressing water quality limited waterbodies. J. Environ. Eng., 130(6), 684-689. http://dx.doi.org/10.1061/(ASCE)0733-9372(2004)130:6(684)

Jackson, C. R., Martin, J. K., Leigh, D. S., \& West, L. T. (2005). A southeastern piedmont watershed sediment budget: Evidence for a multi-millennial agricultural legacy. J. Soil Water Cons., 60(6), 298-310.

Jones, J. I., Murphy, J. F., Collins, A. L., Sear, D. A., Naden, P. S., \& Armitage, P. D. (2012). The impact of fine sediment on macro-invertebrates. River Res. Appl., 28(8), 1055-1071. http://dx.doi.org/10.1002/rra.1516

Kinnell, P. I. A. (2010). Event soil loss, runoff, and the Universal Soil Loss Equation family of models: A review. J. Hydrol., 385(1-4), 384-397. http://dx.doi.org/10.1016/j.jhydrol.2010.01.024

Kochenderfer, J. N., \& Helvey, J. D. (1987). Using gravel to reduce soil losses from minimum-standard forest roads. J. Soil Water Cons., 42(1), 46-50.

Laflen, J. M., Elliot, W. J., Flanagan, D. C., Meyer, C. R., \& Nearing, M. A. (1997). WEPP: Predicting water erosion using a process-based model. J. Soil Water Cons., 52(2), 96-102.

Laflen, J. M., Flanagan, D. C., \& Engel, B. A. (2004). Soil erosion and sediment yield prediction accuracy using WEPP. $J$. American Water Resour. Assoc., 40(2), 289-297. http://dx.doi.org/10.1111/j.1752-1688.2004.tb01029.x

Lane, P. N. J., \& Sheridan, G. J. (2002). Impact of an unsealed forest road stream crossing: Water quality and sediment sources. Hydrol. Proc., 16(13), 2599-2612. http://dx.doi.org/10.1002/hyp.1050

Lang, A. J. (2016). Soil erosion from forest haul roads at stream crossings as influenced by road attributes. PhD diss. Blacksburg, VA: Virginia Tech, Department of Forest Resources and Environmental Conservation.

Liu, B. Y., Nearing, M. A., Baffaut, C., \& Ascough II, J. C. (1997). The WEPP watershed model: III. Comparisons to measured data from small watersheds. Trans. ASAE, 40(4), 945-952. http://dx.doi.org/10.13031/2013.21345 
Luce, C. H., \& Black, T. A. (1999). Sediment production from forest roads in western Oregon. Water Resour. Res., 35(8), 2561-2570.

MacCurdy, M. G., \& Timmons, D. L. (2013). Questions remain for the timber industry after Supreme Courts decision in Decker v. Northwest Environmental Defense Center. Environ. Law, 43, 827-846.

Madej, M. A. (2001). Erosion and sediment delivery following removal of forest roads. Earth Surf. Proc. Landforms, 26(2), 175-190. http://dx.doi.org/10.1002/10969837(200102)26:2<175::AID-ESP174>3.0.CO;2-N

Megahan, W. F., Wilson, M., \& Monsen, S. B. (2001). Sediment production from granitic cutslopes on forest roads in Idaho, U.S. Earth Surf. Proc. Landforms, 26(2), 153-163.

http://dx.doi.org/10.1002/1096-9837(200102)26:2<153::AIDESP172>3.0.CO;2-0

Merritt, W. S., Letcher, R. A., \& Jakeman, A. J. (2003). A review of erosion and sediment transport models. Environ. Model. Software, 18(8), 761-799. http://dx.doi.org/10.1016/S13648152(03)00078-1

Moore, A. D., McLaughlin, R. A., Mitasova, H., \& Line, D. E. (2007). Calibrating WEPP model parameters for erosion prediction on construction sites. Trans. ASABE, 50(2), 507-516. http://dx.doi.org/10.13031/2013.22639

Morris, B. C., Bolding, M. C., \& Aust, W. M. (2014). Sediment contributions of haul road culverts in Virginia. In Proc. 37th COFE Annual Meeting (pp. 22-25). Morgantown, WV: Council on Forest Engineering.

NOAA. (2015). 1981-2010 U.S. climate normals. Asheville, NC: National Oceanic and Atmospheric Administration, National Centers for Environment Information. Retrieved from https://www.ncdc.noaa.gov/data-access/land-based-stationdata/land-based-datasets/climate-normals/1981-2010-normalsdata

Nolan, L., Aust, W. M., Barrett, S. M., Bolding, M. C., Brown, K. R., \& McGuire, K. J. (2015). Estimating costs and effectiveness of upgrades in forestry best management practices for stream crossings. Water, 7(12), 6946-6966. https://doi.org/10.3390/w7126668

NRC. (2008). Hydrologic effects of a changing forest landscape. Washington, DC: National Research Council, Committee on hydrologic impacts of forest management.

Oreskes, N., Shrader-Frechette, K., \& Belitz, K. (1994). Verification, validation, and confirmation of numerical models in the earth sciences. Science, 263(5147), 641-646. http://dx.doi.org/10.1126/science.263.5147.641

Patric, J. H. (1976). Soil erosion in the eastern forest. J. Forestry, 74(10), 671-677.

Pechenick, A. M., Rizzo, D. M., Morrissey, L. A., Garvey, K. M., Underwood, K. L., \& Wemple, B. C. (2014). A multi-scale statistical approach to assess the effects of connectivity of road and stream networks on geomorphic channel condition. Earth Surf. Proc. Landforms, 39(11), 1538-1549. http://dx.doi.org/10.1002/esp.3611

Reid, L. M., \& Dunne, T. (1984). Sediment production from forest road surfaces. Water Resour. Res., 20(11), 1753-1761.

Renard, K. G., Foster, G. R., Weesies, G. A., \& Porter, J. P. (1991). Rusle: Revised universal soil loss equation. J. Soil Water Cons., 46(1), 30-33.

Renard, K. G., Foster, G. R., Weesies, G. A., McCool, D. K., \& Yoder, D. C. (1997). Predicting soil erosion by water: A guide to conservation planning with the Revised Universal Soil Loss Equation (RUSLE). Handbook 703. Washington, DC: USDA Agriculture Research Service.

Robichaud, P. R., \& Brown, R. E. (2002). Silt fences: An economical technique for measuring hillslope soil erosion.
General Tech. Publ. RMRS-GTR-94. Washington, DC: USDA Forest Service.

SAF. (1995). Reauthorization of the Clean Water Act: Forestry effects on water quality. Report to the membership of the Society of American Foresters. SAF 95-10. Bethesda. MD: Society of American Foresters, Task Force on Reauthorization of the Clean Water Act.

Sawyers, B. C., Bolding, M. C., Aust, W. M., \& Lakel, W. A. (2012). Effectiveness and implementation costs of overland skid trail closure techniques in the Virginia Piedmont. J. Soil Water Cons., 67(4), 300-310. http://dx.doi.org/10.2489/jswc.67.4.300

Shepard, J. P. (2006). Water quality protection in bioenergy production: The U.S. system of forestry best management practices. Biomass Bioenergy, 30(4), 378-384. http://dx.doi.org/10.1016/j.biombioe.2005.07.018

Sheridan, G. J., \& Noske, P. J. (2007). Catchment-scale contribution of forest roads to stream exports of sediment, phosphorus and nitrogen. Hydrol. Proc., 21(23), 3107-3122. http://dx.doi.org/10.1002/hyp.6531

Sheridan, G. J., Noske, P. J., Lane, P. N. J., \& Sherwin, C. B. (2008). Using rainfall simulation and site measurements to predict annual interrill erodibility and phosphorus generation rates from unsealed forest roads: Validation against in situ erosion measurements. Catena, 73(1), 49-62. http://dx.doi.org/10.1016/j.catena.2007.08.006

Simanton, J. R., Weltz, M. A., \& Larsen, H. D. (1991). Rangeland experiments to parameterize the Water Erosion Prediction Project model: Vegetation canopy cover effects. J. Range Mgmt., 44(3), 276-282. http://dx.doi.org/10.2307/4002957

Skaugset, A., Surfleet, C., Meadows, M., \& Amann, J. (2011). Evaluation of erosion prediction models for forest roads. Transport. Res. Record: J. Transport. Res. Board, 2203, 3-12. http://dx.doi.org/10.3141/2203-01

Strickler, G. S. (1959). Use of the densiometer to estimate density of forest canopy on permanent sample plots. PNW-180. Portland, OR: USDA Forest Service, Pacific Northwest Research Station.

Stuart, G. W., \& Edwards, P. J. (2006). Concepts about forests and water. Northern J. Appl. Forestry, 23(1), 11-19.

Swift, L. W., \& Burns, R. G. (1999). The three Rs of roads: Redesign, reconstruction, and restoration. J. Forestry, 97(8), 4044.

Taylor, S. E., Rummer, R. B., Yoo, K. H., Welch, R. A., \& Thompson, J. D. (1999). What we know - and don't know about water quality at stream crossings. J. Forestry, 97(8), 1217.

Tiwari, A. K., Risse, L. M., \& Nearing, M. A. (2000). Evaluation of WEPP and its comparison with USLE and RUSLE. Trans. ASAE, 43(5), 1129-1135. http://dx.doi.org/10.13031/2013.3005

Toy, T. J., Foster, G. R., \& Renard, K. G. (1999). RUSLE for mining, construction, and reclamation lands. J. Soil Water Cons., $54(2), 462-467$.

USDA-ARS. (2008). User reference guide for Revised Universal Soil Loss Equation, Ver. 2 (RUSLE2). Draft. Washington, DC: USDA Agriculture Research Service.

USDA-NRCS. (2011). Updated $T$ and $K$ factors Q\&A: Wisconsin. Washington, DC: USDA National Resources Conservation Service.

USDA-NRCS. (2012). Web soil survey. Washington, DC: USDA National Resources Conservation Service. Retrieved from http://websoilsurvey.nrcs.usda.gov/.

USDA-NRCS. (2015). Official NRCS climate database. Washington, DC: USDA National Resources Conservation Service. Retrieved from http://fargo.nserl.purdue.edu/RUSLE2_ftp/Climate_data/. VDOF. (2011). Virgina's forestry best management practices for 
water quality: Technical manual. Charlottesville, VA: Virginia Department of Forestry.

Wade, C. R., Bolding, M. C., Aust, W. M., Lakel III, W. A., \& Schilling, E. B. (2012). Comparing sediment trap data with the USLE-Forest, RUSLE2, and WEPP-Road erosion models for evaluation of bladed skid trail BMPs. Trans. ASABE, 55(2), 403414. http://dx.doi.org/10.13031/2013.41381

Walbridge, T. A. (1997). The location of forest roads. Blacksburg, VA: Walbridge and Associates.
Wear, L. R., Aust, W. M., Bolding, M. C., Strahm, B. D., \& Dolloff, C. A. (2013). Effectiveness of best management practices for sediment reduction at operational forest stream crossings. Forest Ecol. Mgmt., 289, 551-561. http://dx.doi.org/10.1016/j.foreco.2012.10.035

WU. (2013). Weather history for January 2012 through December 2013. Weather Underground. Retrieved from https://www.wunderground.com/history

Zar, J. H. (2010). Biostatistical analysis. Upper Saddle River, NJ: Pearson-Prentice Hall. 